\title{
Effects of common oak (Quercus robur L.) defolition on the soil properties of an oak forest in Western Plain of Romania
}

\author{
A. Onet, A. Teușdea, N. Boja, C. Domuta, C. Onet,
}

Onet A., Teusdea A., Boja N., Domuta C., Onet C., 2016. Effects of common oak (Quercus robur L.) defoliation on the soil properties of an oak forest in Western Plain of Romania. Ann. For. Res. 59(1): 33-47.

Abstract. This study was conducted to evaluate the variability of the chemical properties of the soil of an oak forest affected by defoliation and the corresponding microbial abundance. Soil samples were collected from a control zone (zone 1) without outbreaks of defoliating insects and from a sample zone (zone 2) where the trees were affected by Lymantria dispar L. defoliation. The research was conducted to determine the changed conditions for soil microorganisms produced as a consequence of defoliation. The results indicated, by means of analysis of variance (two-way ANOVA, $\mathrm{P}=0.05)$, statistically significant differences $(\mathrm{P}<0.0001)$ with respect to soil hydrolytic acidity, $\mathrm{pH}$, ammonium nitrogen, heterotrophic bacteria, nitrogen fixing bacteria from genus Azotobacter and fungi. The data revealed a low number of heterotrophic bacteria and low $\mathrm{pH}$ values in samples taken from the area affected by defoliation. Soils under stands of defoliated trees showed higher values with respect to soil acidity, ammonium nitrogen, fungi and nitrogen fixing bacteria Azotobacter. Moreover, the soil moisture, nitrate nitrogen, organic matter content, organic carbon, the number of heterotrophic bacteria and the number of bacteria from genus Azotobacter exhibited statistically significant seasonal differences between the two zones studied. The correlations between the tested parameters showed that soil parameters such as moisture content, soil acidity, $\mathrm{pH}$, organic matter content, organic carbon, total nitrogen and nitrate nitrogen are important factors influencing the soil populations of aerobic mesophilic heterotrophic bacteria, fungi and nitrogen fixing bacteria in the studied forest ecosystem. Keywords forest ecosystems, forest soils, defoliated oak forests, soil microorganisms

Authors. Aurelia Oneț (aurelia_onet@yahoo.com), Alin Teușdea, Cristian Domuța, Cristian Oneț - Faculty of Environmental Protection, University of Oradea ; Nicuşor Boja - Faculty of Natural Sciences, Engineering and Informatics, "Vasile Goldiş" Western University of Arad.

Manuscript received May 05, 2015; revised September 09, 2015; accepted February 12, 2016; online first March 07, 2016. 


\section{Introduction}

Microbes are important organisms that drive the turnover of organic matter in soils. Analyses of microbial activity have become standard procedures in various environmental monitoring programmes. Within this context, the number and the biomass of microorganisms (bacteria, yeasts, fungi), and descriptions and monitoring of microbial communities, are basic requirements for the understanding of microbiological processes. These aspects have become an important part of the remit of soil ecology research (Bölter 2002). In forest soils there is an enormous diversity of soil bacteria, in combination with complex factors regulating their growth and survival. Soil bacteria are an essential component of the biotic community in natural forests and they are largely responsible for ecosystem functioning, because they participate in most nutrient transformation processes. Understanding soil microbial changes associated with forest management is central to linking aboveground and belowground forest structures and functions (Chen et al. 2015). Although the main diversity of life has been proven to be microbial, the vast majority of soil bacteria still remain unknown due to the fact that only a minor percentage of naturally occurring microorganisms can be cultured (Hackl et al. 2004). Physical and chemical analyses do not allow for detailed conclusions to be drawn on the biological structures and functions taking place in the soil. Today the need to develop various indicators to assess the quality, the integrity and the fertility of soils is greater than ever before.

Such indicators should incorporate the heterogeneity of soil types and land uses (Gaublomme et al. 2006). Microbial communities of forest soils decompose organic material and they strongly influence the nutrient cycling of the ecosystem. Frostegård et al. (1993) studied soils of different forest types using plate counts and found that in addition to affecting the activity of the microorganisms, site prop- erties, and their influence in turn on the plant community, also affect the composition and spatial distribution of the microbial community. Tree species can influence soil properties via several mechanisms. Differences between species with respect to foliage and litter quality, root nutrient uptake and activity as well as the corresponding microclimates and the soil biological communities can result in contrasting physical and chemical characteristics of surface soils (Gakis et al. 2014).

Lovett et al. (2002) revealed that defoliation in forest ecosystems brought about by insect outbreaks causes major disruption to these ecosystems with significant alterations to the chemical composition of the soils below. The effects include loss of nitrogen, tree mortality and water drainage. The authors examined the mechanisms and magnitudes of $\mathrm{N}$-cycle perturbations caused by defoliation. The chemistry of the organic matter was also found to be altered. Other studies have shown that defoliation can decrease transpiration and tree growth while increasing light penetration to the forest floor (Campbell \& Sloan 1977). Changes to the tree canopy naturally affect soil due to altered light and temperature conditions, and changes to the physical and chemical soil properties may influence the temporal and spatial heterogeneity of the microbial community. In Romania, the ecosystems formed by oak forests occupy a considerable area (over $20 \%$ of the forested area) (Romania Geography 1992). The main class of soils associated with oak forests is luvisol.

Knowledge of microbial activity in Romania's forest ecosystems and the effects of outbreaks of defoliating insects are limited. The objectives of this study were: (1) to determine whether chemical soil composition and bacterial abundance are significantly affected by outbreaks of defoliating insects; (2) to understand the effects of seasonality on soil chemical and microbiological properties; and (3) to investigate whether the physical and chemical characteristics of oak forest soils influence the 
structure of bacterial communities.

\section{Materials and methods}

The Crisurilor Plain is part of the Western geobotanical region of Romania known as the Cris Plain District, and it is characterised by the Eastern (European Turkey oak - Quercus cerris L. and Hungarian oak - Quercus frainetto Ten.) and Central European (common oak - Quercus robur L.) broadleaved forest ecosystems. The natural vegetation has undergone essential changes, marked by widespread deforestation and conversion to agriculture, the introduction of drainage systems, the replacement of species, etc. Today forest occupies about $4.5 \%$ of the plain area (Mahara 1977).

The shrub layer of the Quercus cerris L. and Quercus frainetto Ten. forests consists of Crataegus monogyna Jacq., Ligustrum vulgare L., Rosa canina L., Cornus mas L., etc. The herbaceous layer comprises Carex genus L., Poa genus L., etc. The forest steppe of the low plain comprise Quercus sp., Fraxinus sp.,Ulmus sp., Populus L. sp., Salix L. sp., Alnus sp. (Romania Geography, 1992). The average annual precipitation at the study sites is 589.2 $\mathrm{mm}$ and the average temperature is $12.3^{\circ} \mathrm{C}$ (Mahara 2001).

The forest area selected for the investigation of the impact on microbial activity of stand defoliation was Cefa-Ateas forest

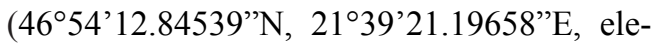
vation $99 \mathrm{~m}$ ), located on Romania's Crisurilor Plain, $30 \mathrm{~km}$ West of Oradea, Bihor County.

The forest covers an area of 198 ha and is located on an alluvial plain situated at a minimum altitude of $92 \mathrm{~m}$ above sea level. The forest type is in the plain oak grove meadow and the forest site type is forest plain. In the Cefa-Ateas forest the majority species are Quercus robur L. (73.14\%) and Fraxinus excelsior L., (19.39\%) followed by Acer campestre L. (4.49\%), Quercus cerris L. (1.57\%), Populus tremula L. (1.12\%), Carpinus betulus L. (0.12\%), Ulmus minor Mill. (0,11\%),
Prunus serotina ( $0.06 \%)$ Ehrh. The trees age is between 25 and 80 years (forest planning document, Oradea Forest District).

Outbreaks of the defoliating insect Lymantria dispar (L.) are a frequent phenomena occurring in the oak forests of Bihor County. Trees (Quercus sp.) on an area covering 141.7 ha within the studied forest were affected by Lymantria dispar (L.) outbreaks (zone 2).The outbreaks had a moderate intensity with $30 \%$ of defoliated trees. Only 3.1 ha remained unaffected by outbreaks of defoliating insects designated the control site (zone 1). In this area have not been reported attacks (negligible population of Lymantria dispar (L.) (information provided by Oradea Forest District). The two zones sampled as part of this study were located relatively close to one another (less than $100 \mathrm{~m}$ apart). The soil of the studied forest area was luvisol (FAO classification) (Deckers 1998).

\section{Field data collection}

Sampling took place twice a year, in spring and autumn (on March 15-19 and October 1-5, year 2013) because the soil microbial activity is more intense in spring and autumn. At the time of the first sample in March the oaks foliage of had not yet flushed and by October leaffall had already taken place. For each zone, Z1 and $\mathrm{Z} 2$, were selected six sampling locations. In each location was established a centre from which was drawn a circle with $20 \mathrm{~m}$ radius. Soil samplings were taken in accordance with the classical square method that uses five sampling units: one in the square centre and four in the square corners. There were done two replications (by square method) with the same centre, but with shifted squares corners as presented in Figure 2. The sampling depth was $0-20 \mathrm{~cm}$. The weight of one sample from each square point was $25 \mathrm{~g}$. The five soil samples from each point of the square (including the centre) were mixed in the laboratory resulting $125 \mathrm{~g}$ of soil sample for each replication, resulting $n=12$ measured values for each pa- 


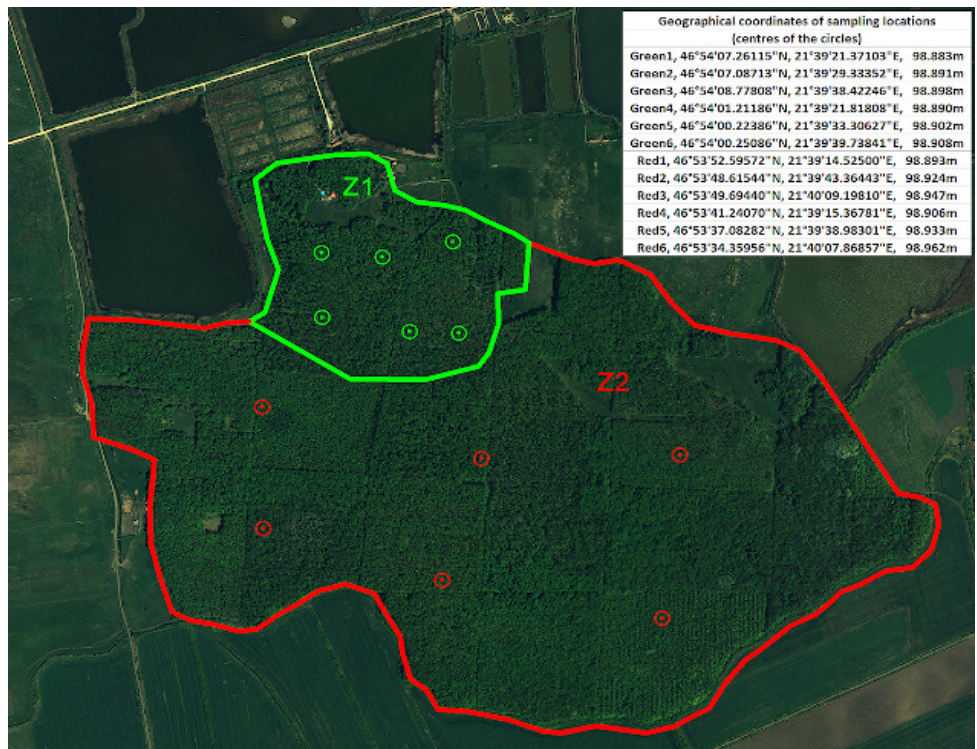

Figure 1 Experimental field map: green contour area represents the control zone Z1 and the red contour area represents the defoliated zone $\mathrm{Z2}$. The circles represent the sampling locations. Source: http://geoportal.gov.ro/viewers/ro_RO/index.html

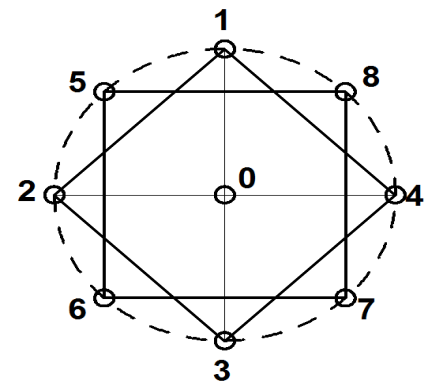

Figure 2 Example of sampling location and the sampling scheme replications of the square method

rameter. After skeleton material and plant roots were removed, the samples were sieved using a Ø $2 \mathrm{~mm}$ sieve, mixed and stored at $4^{\circ} \mathrm{C}$.

\section{Soil analysis}

Soil physical-chemical properties. The physical and chemical properties of the soil samples were determined as follows: moisture content (Ur, \%) was determined using the gravimetric method by oven-drying fresh soil at $105{ }^{\circ} \mathrm{C}$ (drying oven SLW 53 POL EKO); soil acidity (Acid., me/100 g soil) was determined by means of the Kappen procedure; $\mathrm{pH}$ in 1:2.5 soil water suspension using a $\mathrm{pH}$-meter Crison; organic matter content (humus, \%) using the Walkley-Black method; nitrate nitrogen $\left(\mathrm{NO}_{3}-\mathrm{N}\right.$, ppm) was determined using the colorimetric method and ammonium nitrogen $\left(\mathrm{N}-\mathrm{NH}_{4}, \mathrm{ppm}\right)$ with Nessler reagent (UV-VIS Spectrophotometer UV-1700, CPSA 3320.65-ISO 9001, BRML, Shimadzu, Japan). The method used to determine organic carbon (\%) was the wet oxidation method and dosage titration (TOC VCSH, CPSA3320.65-ISO 9001, Shimadzu, Germany) and the Kjeldahl method for total nitrogen (\%) (Kjeldahl system ISO 9001, BRML, Italy, Velp, CPSA 3320.53) (Quinn 2002).

Bacteriological analysis. The quantitative variation between three ecophysiological microbial groups was studied: aerobic 
mesophilic heterotrophic bacteria, fungi and nitrogen fixing bacteria from genus Azotobacter. The plate count method was used to estimate the total number of aerobic mesophilic heterotrophic bacteria on a sterile solid nutrient medium containing meat extract $(\mathrm{pH}$ 7.5, incubation at $37{ }^{\circ} \mathrm{C}, 3$ days) (Atlas 2004), the total number of fungi (yeasts and molds) on Sabouraud dextrose medium ( $\mathrm{pH}$ 5.4-5.6, incubation at $25{ }^{\circ} \mathrm{C}$, 4-5 days) (Washington, 2006) and the total number of nitrogen fixing bacteria from genus Azotobacter on Ashby's glucose agar ( $\mathrm{pH} 7-7.2$, incubation at $35-37^{\circ} \mathrm{C}$ for up to 5 days) (Aquilanti 2004). The inoculated Petri dishes were incubated in the incubator Memmert UNB 100 and after incubation the obtained counts (the colonies of microorganisms were counted with the colony counter POL EKO LKB2002) were multiplied by the dilution factor $\left(10^{6}\right)$ to obtain the number of colony-forming units (CFU) per gram of soil (Bölter 2002).

\section{Statistical analysis}

The statistical methods used to determine the significance of mean differences between the control and the defoliated zones, seasons and the interactions between zones and seasons was a two-way analysis of variance (ANOVA). In order to asses the possibility of samples clustering it was used a multivariate methods sequence of: principal component analysis (PCA), multivariate analysis of variance (MANOVA) and hierarchical cluster analysis.

The samples were analyzed using two-way analysis of variance (ANOVA) $(n=12, \mathrm{P}=$ $0.05)$, in order to determine the statistical significance of differences between means. Comparisons were made between the means of four groups created by mixing the seasonal samples (SPR: spring, AUT: autumn) and the zone samples (Z1 and Z2). The ANOVA results were generated using the software GraphPad Prism version 5.5 (GraphPad Software, San
Diego, CA, www.graphpad.com).Variables correlations (for each season and between the parameters values for Z1 and Z2 zones) were presented as Pearson correlation coefficient; group comparisons and cluster validation were done by means of PCA and hierarchical cluster analysis (HCA) (Quinn 2002; Abdi 2010) using the software PAST version 3.05 (Hammer 2005).

An important criterion for the evaluation of PCA performance is the proportion of the variance explained by the principal components (in our case, PC1, PC2 and PC3). The higher the proportion, the better the PCA performs. The best situations are where greater than $60.0 \%$ of variance is explained by PC1. As natural biosystems are dynamic in their behaviour, $45 \%$ explained variance is more than acceptable for the first principal component. Furthermore, the sum of the explained variances of PC1 and PC2 should sufficiently exceed $80 \%$. This criterion was fully satisfied by PC1 and PC2 in the case of the data collected in this study. With this PCA performance criterion fulfilled, the PCA biplot can be analysed (fig. 5).

A PCA biplot merges in one graphical representation the variable loadings (with vector lines emerging from the centre) and sample scores (indicated by dots and linked by a convex hulls). Loading vectors point out the "direction" of higher abundance of the marked variable. The opposite direction denotes lower variables abundance comprised by the samples convex hulls, pointed by the loading vectors. This is one of the biplot opportunities: possible discrimination between sample groups (in multivariate way), by relative position of sample groups.

\section{Results}

\section{Variation of the physical and chemical prop- erties and bacterial abundance in the soil samples}

Significant differences between spring and au- 
Table 1 Analyses of variance (two-way ANOVA) to assess the effects of defoliation and season on the physical and chemical properties of the soil

\begin{tabular}{|c|c|c|c|c|c|c|c|c|c|c|c|c|}
\hline & \multicolumn{2}{|c|}{ Moisture } & \multirow[b]{2}{*}{$P$} & \multicolumn{2}{|c|}{ Acidity } & \multicolumn{3}{|c|}{$\mathrm{pH}$} & \multicolumn{4}{|c|}{ Organic matter } \\
\hline & $d f$ & $F$ & & $d f$ & $F$ & $P$ & $d f$ & $F$ & $P$ & $d f$ & $F$ & $P$ \\
\hline $\begin{array}{l}\text { Defoliation } \\
(\mathrm{Z})\end{array}$ & 1 & 0.15 & 0.7030 & 1 & 877.19 & $<0.0001$ & 1 & 84.06 & $<0.0001$ & 1 & 0.00 & 0.9640 \\
\hline Season (S) & 1 & 31.46 & $<0.0001$ & 1 & 112.27 & $<0.0001$ & 1 & 00.37 & 0.5550 & 1 & 198.85 & $<0.0001$ \\
\hline \multirow[t]{3}{*}{$\mathrm{Z} \times \mathrm{S}$} & 1 & 19.40 & 0.0010 & 1 & 2.93 & 0.1130 & 1 & 04.10 & 0.0660 & 1 & 011.72 & 0.0050 \\
\hline & \multicolumn{2}{|c|}{$\mathrm{N}-\mathrm{NO}_{3}$} & & & \multicolumn{2}{|c|}{$\mathrm{N}-\mathrm{NH}_{4}$} & \multicolumn{2}{|c|}{ Organic C\% } & & \multicolumn{2}{|c|}{ Total N\% } & \\
\hline & $d f$ & $F$ & $P$ & $d f$ & $F$ & $P$ & $d f$ & $F$ & $P$ & $d f$ & $F$ & $P$ \\
\hline $\begin{array}{l}\text { Defoliation } \\
(\mathrm{Z})\end{array}$ & 1 & 1.47 & 0.2490 & 1 & 6.59 & 0.0250 & 1 & 0.18 & 0.6770 & 1 & 0.03 & 0.860 \\
\hline Season (S) & 1 & 40.35 & $<0.0001$ & 1 & 3.13 & 0.1020 & 1 & 183.25 & $<0.0001$ & 1 & 5.32 & 0.040 \\
\hline $\mathrm{Z} \times \mathrm{S}$ & 1 & 10.07 & 0.0080 & 1 & 30.40 & $<0.0001$ & 1 & 012.60 & 0.0040 & 1 & 0.31 & 0.587 \\
\hline
\end{tabular}

Table 2 Physical and chemical properties of the soil for defoliation and season factors Values in paranthesis represent standard deviations $(n=12)$

\begin{tabular}{lcclcc}
\hline Factor: defoliation & $\mathrm{Z} 1$ & $\mathrm{Z} 2$ & Factor: season & AUT & SPR \\
\hline $\begin{array}{l}\text { Acidity } \\
(\mathrm{me} / 100 \mathrm{~g} \text { soil })\end{array}$ & $2.837^{\mathrm{b}}(0.567)$ & $5.342^{\mathrm{a}}(0.445)$ & $\begin{array}{l}\text { Acidity } \\
(\mathrm{me} / 100 \mathrm{~g} \text { soil })\end{array}$ & $3.641^{\mathrm{b}}(1.433)$ & $4.537^{\mathrm{a}}(1.262)$ \\
\hline $\begin{array}{l}\text { Moisture } \\
(\% \text { volume })\end{array}$ & $18.245^{\mathrm{a}}(0.859)$ & $18.071^{\mathrm{a}}(2.533)$ & $\begin{array}{l}\text { Moisture } \\
(\% \text { volume })\end{array}$ & $16.906^{\mathrm{b}}(1.537)$ & $19.410^{\mathrm{a}}(1.108)$ \\
\hline $\mathrm{pH}(\mathrm{pH}$ units $)$ & $6.230^{\mathrm{a}}(0.106)$ & $5.655^{\mathrm{b}}(0.161)$ & $\mathrm{pH}(\mathrm{pH}$ units $)$ & $5.961^{\mathrm{a}}(0.408)$ & $5.923^{\mathrm{a}}(0.243)$ \\
\hline Humus $(\%)$ & $5.693^{\mathrm{a}}(0.958)$ & $5.689^{\mathrm{a}}(0.573)$ & Humus $(\%)$ & $6.389^{\mathrm{a}}(0.317)$ & $4.993^{\mathrm{b}}(0.181)$ \\
\hline $\begin{array}{l}\text { Nitrate } \\
\text { nitrogen }(\mathrm{ppm})\end{array}$ & $4.121^{\mathrm{a}}(1.254)$ & $3.848^{\mathrm{a}}(0.495)$ & $\begin{array}{l}\text { Nitrate } \\
\text { nitrogen }(\mathrm{ppm})\end{array}$ & $3.267^{\mathrm{b}}(0.614)$ & $4.701^{\mathrm{a}}(0.556)$ \\
\hline $\begin{array}{l}\text { Ammonium } \\
\text { nitrogen }(\mathrm{ppm})\end{array}$ & $10.428^{\mathrm{b}}(1.735)$ & $11.390^{\mathrm{a}}(0.806)$ & $\begin{array}{l}\text { Ammonium } \\
\text { nitrogen }(\mathrm{ppm})\end{array}$ & $11.241^{\mathrm{a}}(0.982)$ & $10.577^{\mathrm{a}}(1.724)$ \\
\hline $\begin{array}{l}\text { Organic carbon } \\
(\%)\end{array}$ & $3.305^{\mathrm{a}}(0.563)$ & $3.279^{\mathrm{a}}(0.324)$ & $\begin{array}{l}\text { Organic carbon } \\
(\%)\end{array}$ & $3.696^{\mathrm{a}}(0.200)$ & $2.888^{\mathrm{b}}(0.101)$ \\
\hline $\begin{array}{l}\text { Total nitrogen } \\
(\%)\end{array}$ & $0.285^{\mathrm{a}}(0.117)$ & $0.292^{\mathrm{a}}(0.048)$ & $\begin{array}{l}\text { Total nitrogen } \\
(\%)\end{array}$ & $0.334^{\mathrm{a}}(0.104)$ & $0.242^{\mathrm{b}}(0.019)$ \\
\hline
\end{tabular}

tumn and between zones (zone 1: no outbreaks of defoliating insects; zone 2: Lymantria dispar (L.) outbreaks) in relation to the counts of microorganisms and the physical and chemical properties of the soil were assessed using two-way ANOVA (Tables 1, 2, 3, 4, Fig. 3-4) and principal component analysis (PCA) (Table 5, Figs. 5-6). Analysis of variance helped to emphasise the dominant factor (defoliation/ season) effect in terms of the variability of soil chemical and microbiological properties.

With respect to the moisture content (Ur), the two-way ANOVA revealed significant differences between the average values according to the season factor $(\mathrm{P}<0.0001)$ and the interaction between zones and seasons $(\mathrm{P}=0.001)$, but not for the defoliation factor $(\mathrm{P}=0.703)$.

The analysis of variance (two-way ANOVA, $\mathrm{P}=0.05)$ also showed significant differences $(\mathrm{P}<0.0001)$ in the acidity values, on the basis 

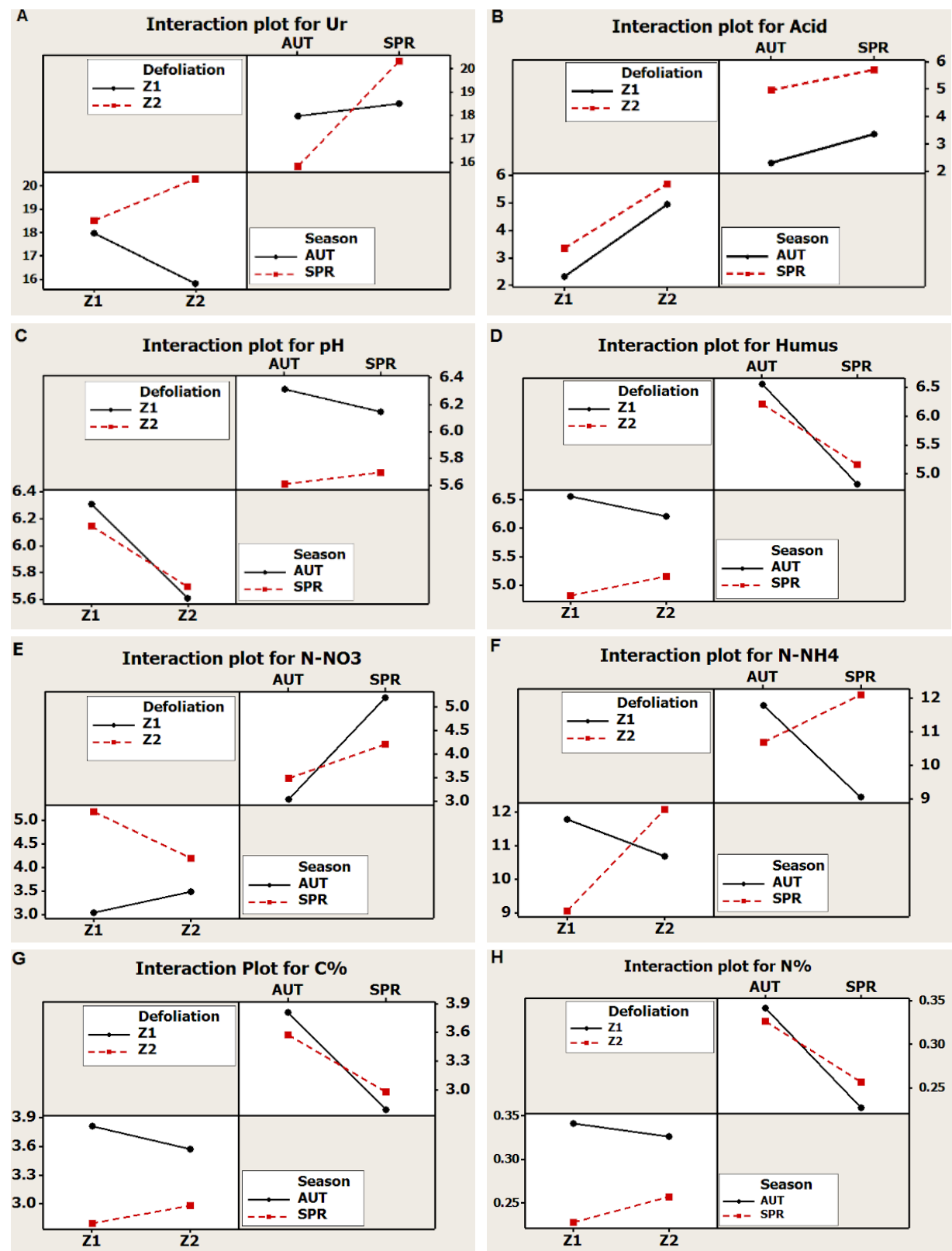

Figure 3 Example of sampling location and the sampling scheme replications of the square method 
of defoliation and season. For $\mathrm{pH}$ the results of the two-way ANOVA showed statistically significant differences only for defoliation $(\mathrm{P}$ $<0.0001)$ but not for season $(\mathrm{P}=0.555)$ or the interaction of both factors $(\mathrm{P}=0.066)$ (Table 1-2, Fig. 3).

The humus content exhibited significant differences between the means for the factor season $(\mathrm{P}<0.0001)$ and the interaction between zone and season $(\mathrm{P}=0.005)$, but not for the factor defoliation $(\mathrm{P}=0.964)$. Statistically significant differences between the mean nitrate nitrogen $\mathrm{N}_{-} \mathrm{NO}_{3}$ values were determined for season $(\mathrm{P}<0.0001)$ and the interaction between zone and season $(\mathrm{P}=0.008)$, but not for defoliation $(P=0.249)$. Statistically significant differences between ammonium nitrogen $\mathrm{N}-\mathrm{NH}_{4}$ means were obtained for defoliation ( $\mathrm{P}$ $=0.025)$ and the interaction between zone and season $(\mathrm{P}<0.0001)$ but not for the factor season $(\mathrm{P}=0.102)$ (Table 1, Fig. 3).

Concerning the chemical parameter the organic $\mathrm{C} \%$, significant differences between means were obtained for season $(\mathrm{P}<0.0001)$ and the interaction between zone and season $(\mathrm{P}$ $=0.004)$ but not for defoliation $(\mathrm{P}=0.677)$.

The results of a two-way ANOVA showed no significant effect of defoliation $(\mathrm{P}=0.860)$, a significant effect of season $(\mathrm{P}=0.040)$ and no significant difference for the interaction between zone and season $(\mathrm{P}=0.587)$ in relation to the chemical parameter the total N\% (Table 1, Fig. 3).

The analysis of variance (two-way ANOVA, $\mathrm{P}=0.05$ ) carried out to determine the changes to microorganism communities arising as a consequence of defoliation showed significant differences $(\mathrm{P}<0.0001)$ with respect to the abundance of aerobic mesophilic heterotrophic bacteria for all three factors: zone, season and the interaction between the two. In spite of this result, the authors investigated the differences in the abundances of aerobic mesophilic heterotrophic bacteria using one-way ANOVA to check for possible anomalies. Table 3-4 reveals that the abundance values for heterotrophic bacteria were lowest in zone Z2. In this 40 case, comparisons of both the defoliation and the season factors with a two-way ANOVA revealed significant differences.

Statistical analysis (two-way ANOVA, P = 0.05 ) of the data for the fungal community revealed significant differences for defoliation $(\mathrm{P}$ $<0.0001)$ and the interaction between factors $(\mathrm{P}=0.003)$. The factor season produced no statistically significant difference $(\mathrm{P}=0.0552)$ for this parameter. This situation was validated by the one-way ANOVA for this parameter (Table $3-4)$, with three groups $(a, b, c)$ present in the post-hoc Tukey test. The results of a two-way ANOVA showed statistically significant differences with respect to the number of nitrogen fixing bacteria Azotobacter for the factors defoliation $(\mathrm{P}<0.0001)$ and season $(\mathrm{P}=0.046)$ but not for the interaction between the two ( $\mathrm{P}$ $=0.668$ ) (Table 3-4, Fig. 4).

\section{Correlations between the tested parameters}

Correlations were performed between the tested variables to investigate whether the physical and chemical characteristics of the soils beneath oak stands influence the microbial community structure.

The research results indicated that in the stands not affected by defoliation (the control site, zone 1) a statistically significant strong negative correlation was observed between the number of fungi and the number of nitrogen fixing bacteria during the spring $(\mathrm{r}=-0.986$; $\mathrm{P}=0.014)$. The number of fungi was strongly correlated with acidity $(\mathrm{r}=0.994 ; \mathrm{P}=0.006)$ and organic matter content $(\mathrm{r}=0.992 ; \mathrm{P}=$ $0.008)$. A strong correlation was observed between acidity and organic matter $(\mathrm{r}=0.981$; $\mathrm{P}=0.019)$ and between organic matter and ammonium nitrogen content $(\mathrm{r}=0.956 ; \mathrm{P}=$ 0.044). Ammonium nitrogen content correlated with the total $\mathrm{N} \%$ content $(\mathrm{r}=0.974 ; \mathrm{P}=$ 0.026 ) and the total N\% was strongly correlated with soil $\mathrm{pH}(\mathrm{r}=0.986 ; \mathrm{P}=0.014)$.

In autumn, the number of heterotrophic bacteria correlated strongly with the number of fungi ( $\mathrm{r}=0.999, \mathrm{P}=0.001)$, and the total 

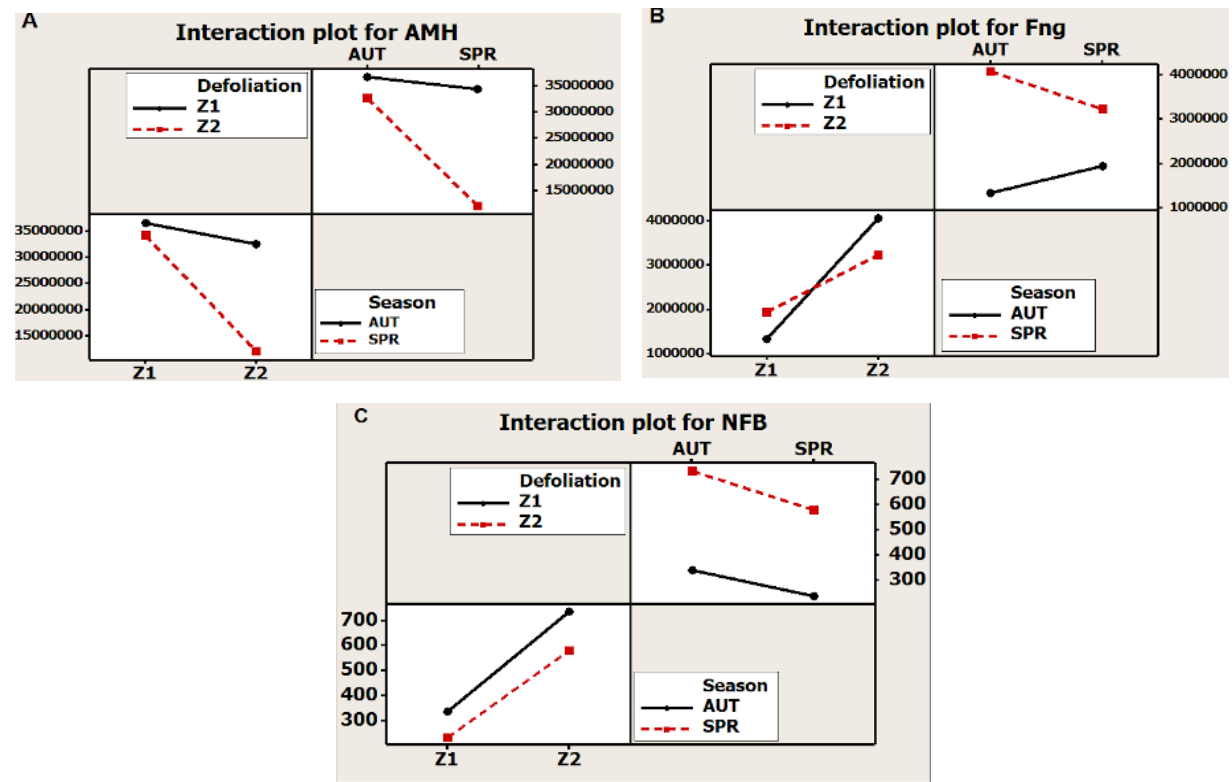

Figure 4 Interaction plots (two-way ANOVA) for the factors defoliation and season for the abundance of microbial communities in the soil

Table 3 Analyses of variance (two-way ANOVA) to estimate the effects of zone and season on microbial community abundance in the soil

\begin{tabular}{lcccccccccc}
\hline & \multicolumn{3}{l}{$\begin{array}{l}\text { aerobic mesophilic } \\
\text { heterotrophs (AMH) }\end{array}$} & \multicolumn{3}{c}{$\begin{array}{l}\text { heterotrophic fungi } \\
\text { (Fng) }\end{array}$} & \multicolumn{4}{c}{$\begin{array}{l}\text { nitrogen fixing bacteria } \\
\text { Azotobacter (NFB) }\end{array}$} \\
\hline $\begin{array}{l}\text { Defoliation } \\
(\mathrm{Z})\end{array}$ & 1 & $F$ & $P$ & $d f$ & $F$ & $P$ & $d f$ & $F$ & $P$ \\
\hline Season (S) & 1 & 51.98 & $<0.0001$ & 1 & 0.37 & 0.5520 & 1 & 4.96 & 0.0460 \\
\hline $\mathrm{Z} \times \mathrm{S}$ & 1 & 32.63 & $<0.0001$ & 1 & 13.33 & 0.0030 & 1 & 0.19 & 0.6680 \\
\hline
\end{tabular}

Table 4 Results of the physical and chemical properties of the soil for defoliation and season factors Values in paranthesis represent the standard deviation $(n=12)$

\begin{tabular}{lcclcc}
\hline \multicolumn{1}{c}{$\begin{array}{c}\text { Factor: } \\
\text { defoliation }\end{array}$} & Z1 & Z2 & $\begin{array}{c}\text { Factor: } \\
\text { season }\end{array}$ & AUT & SPR \\
\hline $\begin{array}{l}\text { AMH } \\
(\mathrm{CFU} / \text { g soil })\end{array}$ & $\begin{array}{r}3.548 \mathrm{E}+07^{\mathrm{a}} \\
\pm 3.919 \mathrm{E}+06\end{array}$ & $\begin{array}{c}2.227 \mathrm{E}+07^{\mathrm{b}} \\
\pm 1.124 \mathrm{E}+07\end{array}$ & $\begin{array}{l}\text { AMH } \\
(\mathrm{CFU} / \mathrm{g} \text { soil })\end{array}$ & $\begin{array}{r}3.465 \mathrm{E}+07^{\mathrm{a}} \\
\pm 3.015 \mathrm{E}+06\end{array}$ & $\begin{array}{c}2.310 \mathrm{E}+07 \mathrm{~b} \\
\pm 1.249 \mathrm{E}+07\end{array}$ \\
\hline $\begin{array}{l}\text { Fng } \\
(\mathrm{CFU} / \mathrm{g} \text { soil })\end{array}$ & $\begin{array}{r}1.637 \mathrm{E}+06^{\mathrm{b}} \\
\pm 4.298 \mathrm{E}+05\end{array}$ & $\begin{array}{r}3.650 \mathrm{E}+06^{\mathrm{a}} \\
\pm 6.245 \mathrm{E}+05\end{array}$ & $\begin{array}{l}\text { Fng } \\
(\mathrm{CFU} / \mathrm{g} \text { soil })\end{array}$ & $\begin{array}{r}2.704 \mathrm{E}+06^{\mathrm{a}} \\
\pm 1.525 \mathrm{E}+06\end{array}$ & $\begin{array}{r}2.583 \mathrm{E}+06^{\mathrm{a}} \\
\pm 7.471 \mathrm{E}+05\end{array}$ \\
\hline $\begin{array}{l}\text { NFB } \\
\text { (CFU/g soil })\end{array}$ & $285^{\mathrm{b}} \pm 64$ & $56^{\mathrm{a}} \pm 171$ & $\begin{array}{l}\text { NFB } \\
(\mathrm{CFU} / \text { g soil })\end{array}$ & $535^{\mathrm{a}} \pm 219$ & $406^{\mathrm{b}} \pm 233$ \\
\hline
\end{tabular}


number of fungi correlated strongly with the nitric nitrogen content $(\mathrm{r}=0.970, \mathrm{P}=0.030)$.

Acidity values were strongly correlated with moisture content $(\mathrm{r}=0.982, \mathrm{P}=0.018)$, organic matter content $(\mathrm{r}=0.994, \mathrm{P}=0.006)$ and ammonium nitrogen content $(\mathrm{r}=0.953, \mathrm{P}$ $=0.047$ ). A statistically significant correlation was obtained between moisture content and organic matter content $(\mathrm{r}=0.983, \mathrm{P}=0.017)$, ammonium nitrogen content $(\mathrm{r}=0.973, \mathrm{P}=$ $0.027)$ and organic $\mathrm{C} \%(\mathrm{r}=0.975, \mathrm{P}=0.025)$. Soil $\mathrm{pH}$ values were strongly correlated with nitrate nitrogen content $(\mathrm{r}=0.959, \mathrm{P}=0.041)$ and organic $\mathrm{C} \%$ content $(\mathrm{r}=0.974, \mathrm{P}=0.026)$, whereas organic matter content correlated strongly with ammonium nitrogen content $(\mathrm{r}$ $=0.979, \mathrm{P}=0.021)$ and total $\mathrm{N} \%$ content $(\mathrm{r}$ $=0.965, \mathrm{P}=0.035)$. Strong correlations were also observed between ammonium nitrogen content, organic $\mathrm{C} \%$ content $(\mathrm{r}=0.981, \mathrm{P}=$ $0.019)$ and total $\mathrm{N} \%$ content $(\mathrm{r}=0.980, \mathrm{P}=$ $0.020)$.

In spring within zone 2, the number of aerobic heterotrophic bacteria correlated strongly with the number of fungi $(\mathrm{r}=0.994, \mathrm{P}=$ 0.006), and the number of fungi exhibited a strong positive correlation with the total number of nitrogen fixing bacteria Azotobacter ( $\mathrm{r}$ $=0.955, \mathrm{P}=0.045)$. Acidity values correlated strongly with the ammonium nitrogen content $(\mathrm{r}=0.954, \mathrm{P}=0.046)$ and strong correlations were also present between moisture content, organic matter content $(\mathrm{r}=0.970, \mathrm{P}=0.030)$ and organic $\mathrm{C} \%(\mathrm{r}=0.982, \mathrm{P}=0.018)$. Organic matter content was strongly correlated with organic $\mathrm{C} \%$ content $(\mathrm{r}=0.992, \mathrm{P}=0.008)$.

The autumn data for zone 2 revealed the number of heterotrophic bacteria to be strongly correlated with moisture content $(\mathrm{r}=0.957$, $\mathrm{P}=0.043)$, organic matter content $(\mathrm{r}=0.998, \mathrm{P}$ $=0.002)$ and organic $\mathrm{C} \%$ content $(\mathrm{r}=0.996, \mathrm{P}$ $=0.004)$.

A strong correlation was observed between the number of fungi and $\mathrm{pH}$ value $(\mathrm{r}=0.961$, $\mathrm{P}=0.039$ ), and the number of nitrogen fixing bacteria Azotobacter correlated negatively with the nitrate nitrogen content $(\mathrm{r}=-0.981$, $\mathrm{P}=0.019)$ and total $\mathrm{N} \%$ content $(\mathrm{r}=-0.963$, $\mathrm{P}=0.037)$. The moisture content correlated strongly with the organic matter content $(\mathrm{r}=$ $0.974, \mathrm{P}=0.026$ ). There was also a strong correlation between organic matter content and organic $\mathrm{C} \%(\mathrm{r}=0.987, \mathrm{P}=0.013)$.

\section{Multivariate analysis}

A multivariate analysis was performed to obtain information about variable and sample grouping or clustering. Between groups and variables correlation matrices were used to perform the principal component analysis (PCA). The principal component output was summarised in a PCA table (5). Eigenvalues for the first two principal components were close, and approximately three times greater than that of the third; the same situation was observed for the percentage variability explained by the principal components. The eigenvalue of the third principal component was greater than unit, indicating that this principal component is important with respect to variable and sample grouping (Table 3 ).

The first result emerging from the biplot were the analysis consisted in the non-overlapping positions of the sample groups SPR_Z1, AUT_Z1, SPR_Z2 and AUT_Z2, indicating the multivariate separation of the groups by the variables (all together) from the experiment.

Sample group SPR_Z1 exhibited negative scores for PC1 and PC 2 and high abundance of variables $\mathrm{pH}$, moisture content, nitrate nitrogen and aerobic mesophilic heterotrophic bacteria, while sample group AUT Z1 revealed positive scores for $\mathrm{PC} 1$ and negative scores for $\mathrm{PC} 2$, with high abundance of variables $\mathrm{pH}$, heterotrophic bacteria, organic matter content, organic $\mathrm{C} \%$, total $\mathrm{N} \%$ and ammonium nitrogen (Fig. 5).

Sample group SPR_Z2 revealed negative scores for PC1, positive for PC2 and high abundance of the variables acidity, fungi and nitrogen fixing bacteria Azotobacter, while 
Table 5 PCA Principal component statistics

\begin{tabular}{llll}
\hline PC & Eigenvalue & Variance (\%) & Cumulative variance (\%) \\
\hline 1 & 4.98390 & 45.308 & 45.308 \\
\hline 2 & 4.34626 & 39.511 & 84.819 \\
\hline 3 & 1.66984 & 15.180 & 99.999 \\
\hline
\end{tabular}

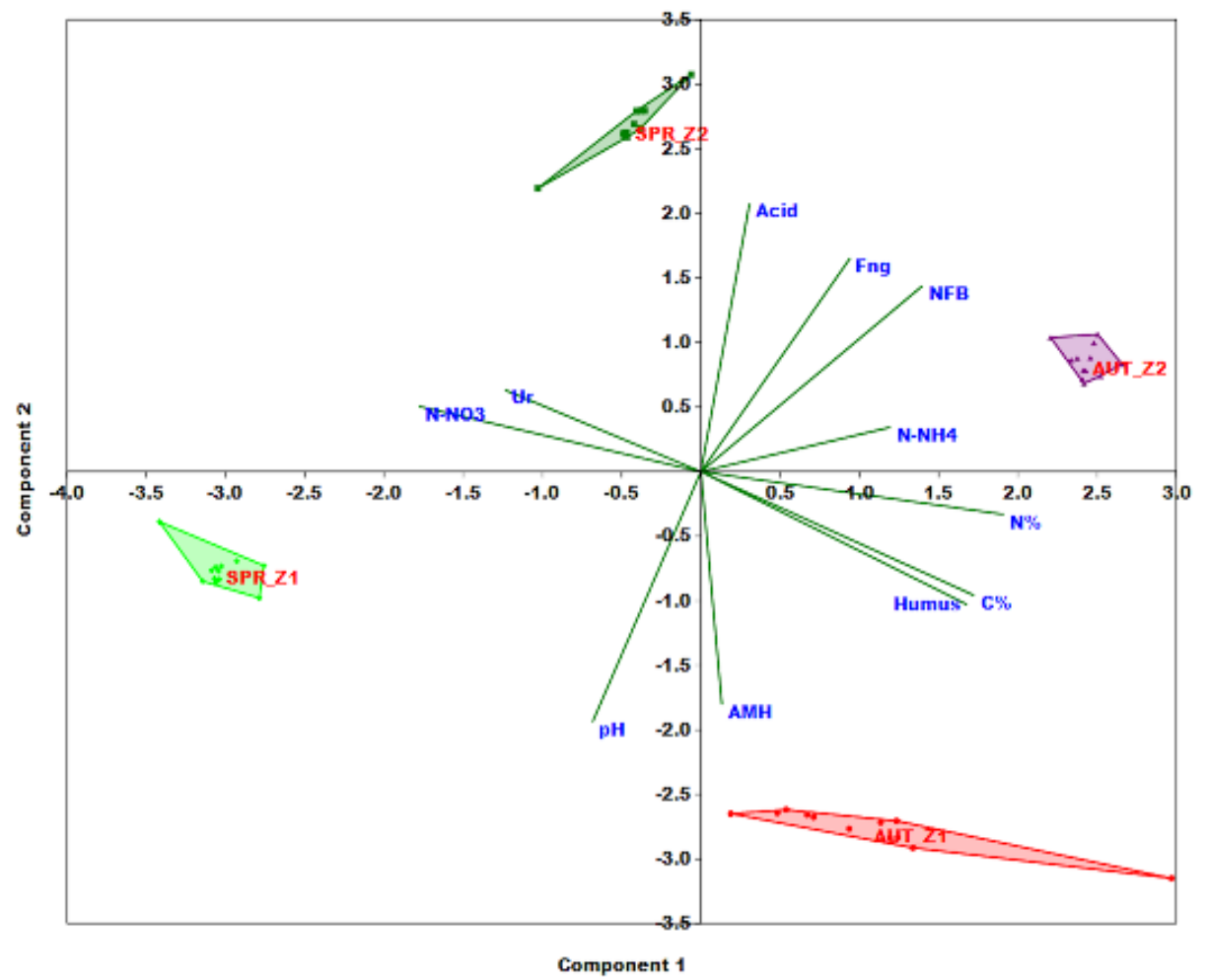

Figure 5 Interaction plots (two-way ANOVA) for the factors defoliation and season for the abundance of microbial communities in the soil

sample group AUT_Z2 produced positive scores for PC1 and PC 2 , with high abundance of the variables organic matter, organic $\mathrm{C} \%$, total N\%, fungi, nitrogen fixing bacteria $\mathrm{AzO}$ tobacter and ammonium nitrogen.

If one considers the $\mathrm{Z} 1$ sample group (SPR Z1 and AUT_Z1 combined) and the Z2 sample group (SPR_Z2 and AUT_Z2 combined), the variables that discriminate them are those revealing a high correlation with PC2: acidity, fungi and Azotobacter, with PC2 positive loadings; and $\mathrm{pH}$ and aerobic mesophilic hetero- trophic bacteria, with PC2 negative loadings. Furthermore, if one considers the SPR sample group (SPR_Z1 and SPR_Z2 combined) and AUT sample group (AUT_Z1 and AUT_Z2 combined) (Fig. 5), the discrimination variables for the season factor sampling groups were those with high PC1 correlations: ammonium nitrogen, organic matter, organic $\mathrm{C} \%$ and total N\% with positive PC1 loadings, and moisture and nitrate nitrogen with negative PC1 loadings. Sample clustering was investigated by means of hierarchical cluster analy- 
Table 6 Statistical significances of the pair wise comparisons of samples with MANOVA multivariate test

\begin{tabular}{lllll}
\multicolumn{1}{c}{$(n=12)$} & & & \\
\hline MANOVA & AUT_Z1 & SPR_Z1 & AUT_Z2 & SPR_Z2 \\
\hline AUT_Z1 & & $<0.0001$ & $<0.0001$ & $<0.0001$ \\
\hline SPR_Z1 & $<0.0001$ & & $<0.0001$ & $<0.0001$ \\
\hline AUT_Z2 & $<0.0001$ & $<0.0001$ & & $<0.0001$ \\
\hline SPR_Z2 & $<0.0001$ & $<0.0001$ & $<0.0001$ & \\
\hline
\end{tabular}

Note. Abreviations: Abreviations: SPR_Z1 and AUT_Z1 - spring and autumn samples from defoliation zone Z1; SPR_Z2 and AUT_Z2 - spring and autumn samples from defoliation zone Z2.

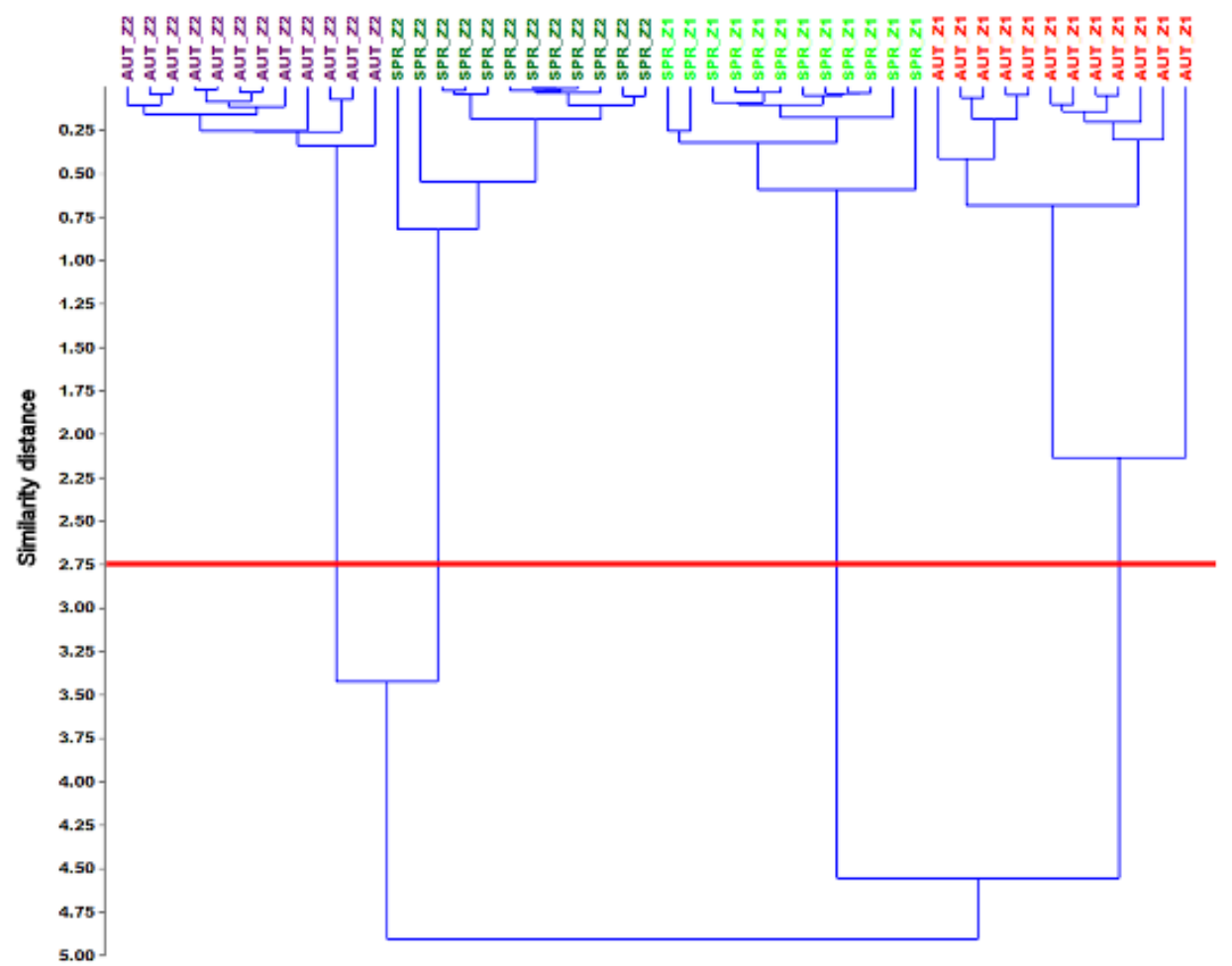

Figure 6 Dendrogram depicting the hierarchical cluster analysis (HCA) performed on samples and first two principal components scores

sis (HCA), with a UPGMA paired group and Euclidean similarity measure of the principal component analysis results (i.e., PCA scores of the samples consisted as the HCA input data) (Fig. 6). The MANOVA test had as in- put data the PCA scores of the samples and the results validate four samples clusters (based on the statistical significance) (see Table 6). These four complete non-overlapping samples clusters are generated at a similarity distance 
threshold value of 2.75 (red horizontal line) in the HCA dendrogram (Fig. 6).

\section{Discussion}

According to some authors, defoliation can influence soil chemistry and soil microbial communities in forest ecosystems (Lovett et al., 2002). In this study the changes occurring in soils under oak forest stands affected by defoliation were investigated, also taking into account other factors that might influence the abundance of soil microorganisms such as seasonal variation.

The insect outbreaks influenced chemical composition and microbial abundance in the studied soils significantly. In those areas affected by insect defoliation (zone 2) the topsoil acidity values were higher than in the control zone (zone 1) where the trees were not affected by defoliating insects. The $\mathrm{pH}$ values were lower in zone 2 than in zone 1 . In the defoliated area ammonium nitrogen content was higher than under the control stands (table 1). The dominant form of nitrogen in forest soils is $\mathrm{NH}_{4}^{+}-\mathrm{N}$ (Ahangar, 2012). The potential for ammonification may be high under defoliated stands due to the high activity of ammonifying microorganisms after leaf-fall (Stremiñska, 2006).

Forest soil scientists have long been concerned with soil carbon and nitrogen because these are the main variables determining soil fertility (Johnson \& Curtis, 2001). Mellec et al. (2008) reported that defoliators significantly alter element and nutrient cycling in forests, thus directly and indirectly affecting ecosystem functioning. Our results contradict previous studies and showed that the concentrations of organic carbon and total nitrogen remained stable without statistically significant differences between the healthy stand and the stand subjected to defoliation. The abundance of heterotrophic bacteria was also affected where Lymanthria dispar L. infestation occurred (Ta- ble 3-4).

Fungi are well known agents of decomposition of organic matter, in general, and of cellulosic substrates in particular (Sri Lakshmi, 2012). In the studied Romanian oak forest, the numbers of fungi in the soil were high under stands affected by defoliation because they prefer an acid $\mathrm{pH}$ (in both seasons the lowest $\mathrm{pH}$ values were recorded in zone 2) and the presence of plant material residues offers optimal conditions for their development (Table 3-4). The same results were obtained by Stremiñska (2006), who described high numbers of fungi in the soils of sites affected by insect outbreak. The number of nitrogen fixing bacteria increased significantly in the soil under tree stands with outbreaks of defoliating insects.

The results of the analysis of statistical correlations between the studied soil parameters revealed that in the pedunculate oak forest investigated in Romania's Western Plain soil parameters such as moisture content, acidity, organic matter content, organic $\mathrm{C} \%$ and nitrate nitrogen content are the major driving factors of bacterial communities. Similar findings were presented by other authors: Preem et al. (2012) reported that the physical and chemical characteristics of forest soils beneath alder stands influence the bacterial community structure. They found significant correlations between the relative abundance of bacteria and soil chemical parameters $(\mathrm{pH}$, nitrate nitrogen, organic matter content).

In the case of forest soils, the more balanced temperature regime, moisture regime and nutrient content serves to reduce the overall numbers of bacteria and fungi (Cardelli et al. 2012). Drenovski et al. (2010) stated that the main factor driving composition and microbial biomass was land-use type, especially as it relates to water availability and disturbance.

Distinct microbial communities are associated with certain land-use types and disturbances at the regional scale. These authors suggested that agricultural management can have much 
greater effects on soil microbial communities than forestry. Soil microorganisms respond very quickly to various natural and anthropogenic pressures or stresses acting on the soil ecosystem (Pal et al. 2012).

Dequiedt et al. (2009) claimed that soil microbial community structure and activity is shaped by a multitude of factors, including climate (seasonality), soil type, land cover and edaphic factors. In forest soil, seasonality and soil properties may influence both the taxonomical and functional structure of microbial communities (Rasche et al., 2010). The results presented here showed significant differences between seasons for the following parameters: moisture content, acidity, organic matter content, nitrate nitrogen content, organic $\mathrm{C} \%$, total $\mathrm{N} \%$, heterotrophic bacteria and nitrogen fixing bacteria (Tables 1-4, Fig. 3-4). Grouping variables (Fig. 5-6) revealed positive, strong and statistically significant correlations for the four groups (aerobic mesophilic heterotrophic bacteria and $\mathrm{pH}$; organic matter, organic $\mathrm{C} \%$, total $\mathrm{N} \%$ and $\mathrm{N}-\mathrm{NH}_{4}$; fungi, nitrogen fixing bacteria and acidity; moisture content and $\mathrm{N}-\mathrm{NO}_{3}$ ). The combination of these variables was valid and did not depend on the area and season. As a consequence, discrimination according to the factors defoliation and season was performed according to these groups.

\section{Conclusions}

From the findings of this study it was possible to conclude that defoliating insects influence the soil chemical parameters and the number of cultivable microbial communities in the soil beneath oak forest stands. One-way analysis of variance revealed significant differences between the soil under tree stands subjected to defoliation and that under healthy stands in relation to acidity, $\mathrm{pH}$, ammonium nitrogen, heterotrophic bacteria, fungi and nitrogen fixing bacteria. Soils under defoliated stands showed significantly higher values of hydrolytic acidity (with an increase of $88.2 \%$ ), ammonium 46 nitrogen (with $8.455 \%$ ) and lower $\mathrm{pH}$ values (with $10 \%$ ) compared to healthy stands. The abundance of cultivable heterotrophic bacteria was significantly lower in the soil under the trees defoliated by Lymanthria dispar L. but the number of fungi recorded was higher. The number of heterotrophic bacteria decreased by $59.3 \%$, whereas the number of fungi increased by $145 \%$.The spring time abundance of heterotrophic bacteria in the defoliated areas was less than half as much as all the other values. The number of Azotobacter was $144 \%$ higher in the soil under defoliated stands. In the studied oak forest the populations of fungi and nitrogen fixing bacteria proved to be the most active microbial groups in the soil during the outbreaks of defoliating insects. Both groups proved to be abundant in the soils of the defoliated stands. The correlations between the tested parameters may provide evidence that microorganism abundance is controlled by various soil conditions, and that many soil properties interact with one another.

\section{Acknowledgements}

The preparation of this paper was financially supported within the project "Horizon 2020 - Doctoral and Postdoctoral Studies: Promoting the National Interest through Excellence, Competitiveness and Responsibility in the Field of Romanian Fundamental and Applied Scientific Research," contract number POSDRU/159/1.5/S/140106. The project was co-financed by the European Social Fund under the Sectoral Operational Programme for Human Resources Development 2007-2013. Investing in people!

\section{References}

Abdi H., Williams Lynne J. 2010. Principal Component Analysis. John Wiley \& Sons, Inc.

Ahangar M.A., DarG.H., Bhat Z.A., 2012. Growth response and nutrient uptake of blue pine (Pinus wallichiana) seedlings inoculated with rhizosphere microor- 
ganisms under temperate nursery conditions. Annals of Forest Research 55(2): 217-227.

Aquilanti L., Favilli F., Clemeti F., 2004. Comparison of different strategies for isolation and preliminary identification of Azotobacter from soil samples. Soil. Biol. Biochem.36:1475-1483. DOI: 10.1016/j.soilbio. 2004.04.024

Atlas R.M., 2004. Handbook of microbiological media. $3^{\text {rd }}$ edition. CRC Press, New York. DOI: 10.1201/ 9781420039726

Bölter M., Bloem J., Meiners K., Möller R., 2002. Enumeration and biovolume determination of microbial cells - a methodological review and recommendations for applications in ecological research. Biology and Fertility of Soils 36(4): 249-259. DOI: $10.1007 / \mathrm{s} 00374-002-0537-6$

Campbell R.W., Sloan R.J., 1977. Forest stand responses to defoliation by the gypsy moth. Forest Science Monograph 19:1-32.

Cardelli R., Marchini F., Saviozzi A., 2012. Soil organic matter characteristics, biochemical activity and antioxidant capacity in Mediterranean land use systems. Soil Tillage Research 120: 8-14. DOI: 10.1016/ j.still.2012.01.005

Chen X.L., Wang D.W., Wang J., Diao J.J., Zhang J., Guan Q.W., 2015. Soil microbial functional diversity and biomass as affected by different thinning intensities in a Chinese fir plantation. Applied Soil Ecology 92: 35-44. DOI: 10.1016/j.apsoil.2015.01.018

Deckers J.A., Nachtergaele F.O., Spaargaren O.C. (Eds), 1998. World Reference Base for Soil Resources. Introduction ISSS/ISRIC/FAO. Acco, Leuven/Amersfoort: $165 \mathrm{pp}$.

Dequiedt S., Thioulouse J., Jolivet C., Saby N., Lelievre M., Maron P.A., Martin M.P., Bouré N.C., Toutain B., Arrouays D., Lemanceau P., Ranjard L., 2009. Biogeographical patterns of soil bacterial communities. Environmental Microbiology Reports 1(4): 251-255. DOI: 10.1111/j.1758-2229.2009.00040.x

Drenovski E.R, Steenwerth K.L., Jackson L.E., Scow K.M., 2010. Land use and climatic factors structure regional patterns in soil microbial communities. Global Ecology and Biogeography19(1): 27-39. DOI: 10.1111/j.1466-8238.2009.00486.x

Frostegård Å., Bååth E., Tunlid A., 1993. Shifts in the structure of soil microbial communities in limed forests as revealed by phospholipid fatty acid analysis. Soil Biology and Biochemistry 25: 723-730. DOI: 10.1016/0038-0717(93)90113-P

Gakis S., Orfanoudakis M., Papaioannou A., Mantzanas K., Papanastasis V., Alifragis D., Seilopoulos D., Kostakis S., 2014. Long term evolution of tree growth, understorey vegetation and soil properties in a silvopastoral system of northern Greece. Annals of Forest Research 57(2): 247-265.

Gaublomme E., De Vos B., Cools N., 2006. An indicator for microbial biodiversity in forest soils. INBO. R.2006.40 Instituutvoor Natuur- en Bosonderzoek, Brussels: 129.

Hackl E., Zechmeister-Boltenstern S., Bodrossy L., Ses- sitsch A., 2004. Comparison of diversities and composition of bacterial populations inhabiting natural forest soils. Applied Environmental Microbiology. 70(9): 5057-5065. DOI: 10.1128/AEM.70.9.5057-5065.2004

Hammer Ø., Harper D.A.T., Ryan P.D., 2001. PAST: Paleontological statistics software package for education and data analysis. Palaeontologia Electronica 4(1).

Johnson D., Curtis D., 2001. Effects of forest management on soil C and N storage:meta analysis. Forest Ecology and Management 140: 227-238. DOI: 10.1016/S03781127(00)00282-6

Lovett M.G., Christenson L.M., Groffman P.M., Jones C.G., Hart J.E., Mitchell M.J., 2002. Insect defoliation and nitrogen cycling in forests. Bioscience 54(4): 335-341. DOI: 10.1641/0006-3568(2002)052[0335: IDANCI]2.0.CO;2

Mahara Gh., 2001. Meteorologie [Meteorology]. University of Oradea Publishing House.

Mahara Gh., 1977. Câmpia Crișurilor [Crișurilor Plain]. In: Crișurilor Plain, Fast Criș, Beiuș Country. Scientific and Encyclopaedic Publishing House.

Mellec A., Michalzik B., 2008. Impact of a pine lappet (Dendrolimus pini) mass outbreak on $\mathrm{C}$ and $\mathrm{N}$ fluxes to the forest floor and soil microbial properties in a Scots pine forest in Germany. Canadian Journal of Forest Research 38(7): 1829-1841. DOI: 10.1139/X08-045

Pal S., Panwar P., Bhardwaj D.R., 2012. Soil quality under forest compared to other land uses in acid soil of North Western Himalaya, India. Annals of Forest Research 56(1): 187-198.

Preem J.,Truu J., Truu M., Mander U., Oopkaup K., Lohmus K.,2012. Bacterial community structure and its relationship to soil physico-chemical characteristics in alder stands with different management histories. Ecological Engineering 49: 10-17. DOI: 10.1016/j.ecoleng.2012.08.034

Quinn G.P., Keough M.J., 2002. Experimental design and data analysis for biologists. Cambridge University Press, The Edinburgh Building, Cambridge CB2 2RU, UK, 542 p. DOI: 10.1017/CBO9780511806384

Rasche, F., Knapp D., Kaiser C., Koronda M., Kitzler B., Boltenstern S., Richter A., Sessitsch A., 2010. Seasonality and resource availability control bacterial and archaeal communities in soils of a temperate beech forest. The ISME Journal Mutidiciplinnary Journal of Microbial Ecology 5:389-402.

Sri Lakshmi A., Narasimha G., 2012. Production of cellulases by fungal cultures isolated from forest litter soil. Annals of Forest Research 55(1): 85-92.

Stremiñska M.A., Blaszczyk M., Kolk A., 2006. Microbial abundance and some of their physiological activities in soil organic horizon of pine forest affected by insect herbivory. Polish Journal of Environment Studies 15(6): 905-914.

Winn W., Allen S., Jande W., Koneman E., Procop G., Schreckenberger P., Woods G., 2006. Koneman's Color Atlas and Textbook of Diagnostic Microbiology, sixth edition. Lippincott Williams \& Wilkins, Publisher. 